\title{
STRUCTURAL COMPONENTS OF EMOTIONAL STABILITY IN MUSIC-PERFORMANCE ACTIVITIES OF CHILDREN'S MUSIC SCHOOL STUDENTS
}

\author{
СТРУКТУРНІ КОМПОНЕНТИ ЕМОЦІЙНОÏ СТІЙКОСТІ \\ В МУЗИЧНО-ВИКОНАВСЬКІЙ ДІЯЛЬНОСТІ УЧНІВ ДИТЯЧОї \\ МУЗИЧнОї школИ
}

UDC 61:02-19/374-9

DOI https://doi.org/10.32843/2663$6085 / 2021 / 41 / 2.17$

\section{Tang Zhong,}

Graduate Student at the Department of Pedagogy

Sumy State Pedagogical University named after A.S. Makarenko

\begin{abstract}
In modern society, professional activity makes ever higher demands on the intellectual, psychological, and physical resources of a person. Modern psychology pays considerable attention to the problem of the optimal psychological state of a person in various areas of professional activity, such as astronautics, flying professions, sports, as well as in specific areas of human life (in the Arctic, highlands, deserts, etc.). However, the study of the musician's activities is performer on the concert stage began to attract the attention of specialists quite recently. Performing on the concert stage of a musician-performer is a bright moment full of emotional changes, physical, dynamic overloads, on the one hand, on the other hand, this activity is controlled by both the audience and the musician-performer himself. The analysis of special literature and dissertations, which highlight current issues of emotional stability in the musical performance of students of children's music school, gives grounds to state that a holistic scientific and pedagogical study was not carried out. The aim of the article is to study the structural components of emotional stability in the musical performance of students of children's music school. The methodological basis of the study are dialectical and systematic methodologies used in the field of pedagogical research. General scientific and logical methods are used, namely: analysis, synthesis, induction and deduction, historical and comparative methods. The article is an attempt to explore the structure of emotional stability in the musical performance of students of children's music school. In this aspect, the author investigated and analyzed the motivational, emotional, volitional and intellectual components of the studied education. Key words: emotional stability, components of emotional stability, music school, students of children's music school, music performance.
\end{abstract}

У сучасному суспільстві просресійна діяльність висуває дедалі вищі вимоги до інтелектуальних, психологічних i орізичних ресурсів людини. Сучасна психологія клю- чову увагу приділяє проблемі оптимального психологічного стану людини в різних галузях профессійної діяльності, наприклад космонавтиці, льотній професії, спорті, а також у специфрічних галузях життєдіяльності людини (в Арктиці, на високогір'ях, у пустелях тощо). Натомість дослідження діяльності музиканта-виконавия в концертній естраді стало привертати увагу фахівців недавно. Виступ на концертній естраді музиканта-виконавця - це, з одного боку, яскравий, насичений емоційними перепадами, ффізичними й динамічними перевантаженнями момент, а з іншого-діяльність що має контрольований характер із боку як публіки, так і самого музиканта-виконавця. Аналіз спеціальної літератури та дисертаційних робіт, у яких висвітлено актуальні питання формування емоційної стійкості в музично-виконавській діяльності учнів дитячої музичної школи, дає підстави констатувати, що цілісне науково-педагогічне дослідження зазначеного питання в цих роботах не було здійснене. Метою статті $є$ дослідження структурних компонентів емоційної стійкості в музично-виконавській діяльності учнів дитячої музичної школи. Методологічну основу дослідження становлять діалектична та системна методології, що застосовуються у сфрері педагогічних досліджень. Використано загальнонаукові та логічні методи, а саме: аналіз, синтез, індукцію й дедукцію, історичний та компаративний методи. Стаття $\epsilon$ спробою дослідити структуру емоційної стійкості в музично-виконавській діяльності учнів дитячої музичної школи. У цьому аспекті автором розглянуто й проаналізовано мотиваційний, емоційний, вольовий та інтелектуальний компоненти досліджуваного утворення.

Ключові слова: емоційна стійкість, компоненти емоційної стійкості, музична школа, учні дитячої музичної школи, музично-виконавська діяльність.
Formulation of the problem in general. The problem of emotional stability in public speaking is one of the most important in music pedagogy and psychology. The ability to control oneself at the time of performance and to regulate pop excitement is a mandatory task in the formation of fitness for performance.

The concert performance is the final stage in the work on the musical work. Often it reduces to almost zero all the hard work - both student and teacher. With pleasure and great diligence in class, the student plays on stage with textual losses, with breakdowns, without thinking about the musical image in the work.
There is a contradiction between the student's desire to perform a piece of music at an exam, a concert and the inability to achieve this due to increased excitement.

Analysis of recent research and publications. The main provisions of the theory of music psychology are revealed in the works of L. Bochkarev, A. Gotsdiner, V. Petrushin, and others; the concept of the dynamic structure of the personality is considered in the works of $\mathrm{K}$. Platonov; the concept of pedagogical work - in the researches of N. Kuzmina, A. Markova, A. Rean and others; research in the field of personality anxiety is devoted to the works of L. Kostin, 
B. Kochubey, A. Prikhozhan, etc.; the concepts of socialization and social adaptation of the individual are considered in the studies of A. Mudrik, A. Rean, A. Kudashev, A. Baranov, L. Kostina, A. Prikhozhan, and others.

Valuable advice on psychological preparation of the performer for a concert performance is contained in books, articles, memoirs, methodical developments of outstanding musicians, psychologists and teachers: A. Alekseev, L. Bochkarev, A. Gotsdiner, V. Grigoriev, G. Kogan, G. Neuhaus, V. Petrushina, E. Fedorova and others.

Selection of previously unsolved parts of the overall problem. However, the analysis of special literature and dissertations, which highlight current issues of emotional stability in the musical performance of students of children's music school, gives grounds to state that a holistic scientific and pedagogical study was not carried out.

The purpose of the article is to study the structural components of emotional stability in the musical performance of students of children's music school.

Presenting main material. The psychological structure of emotional stability is distinguished by its complexity, due, on the one hand, to the versatility of the structure of this mental education, on the other hand, to a variety of factors influencing the process of its formation and manifestation. The term "stability" comes from the adjective "stable", and means: first, "standing", "holding firmly, not hesitating, not falling"; secondly, "not subject to fluctuations, constant, persistent, solid". Stability indicates the personal resource of a person as a complex highly organized system, his ability to maintain balance and stability of mental states in constantly changing life circumstances [5].

It should be emphasized that emotional stability is an integral characteristic of a personality that ensures its readiness to withstand stressful influences in difficult situations, and it includes, according to K. Levin, the ability to withstand excessive arousal and emotional stress arising under the influence of stressors, as well as the ability to maintain a high level of activation without interfering with activity. Emotional stability is formed simultaneously with the development of an integral personality and depends on the type of a person's nervous system, his social experience, on previously acquired behavioral skills, and also on the level of development of the basic cognitive structures of the personality [4].

In Russian psychology, there are four approaches to understanding emotional stability. The first is characterized by the reduction of emotional stability to manifestations of will. It is known that different mental processes can interact and interfere with each other (support, strengthen, suppress, etc.). So, for example, a person can, by volitional effort, by means of autogenous training, change his emotional state. Dwelling on this point as the main one, some authors interpret emotional stability as the ability to control emerging emotions when performing an activity. V. Ponomarenko points out that emotional stability should be understood, on the one hand, immunity to emotiogenic factors that have a negative impact on the mental state of a person, and on the other hand, the ability to control and restrain arising asthenic emotions, thereby ensuring successful execution necessary actions [7].

The second approach presented in the works of P. Zilberman [2], V. Kovaleva [3] is based on the fact that mental processes are characterized by integration, the result of which is complex mental formations. Various mental phenomena can enter into them. This also applies to emotional stability. As a result, a number of authors define it as an integrative personality trait.

The third approach is based on the unity of energy and information characteristics of mental properties, on the theory of self-organization of cybernetic systems. Emotional stability is possible in this case on the basis of the reserves of neuropsychic energy, which is associated with the peculiarities of the temperature, the strength of the nervous system in relation to excitation and inhibition, mobility, mobility of nervous processes.

In the fourth approach of the authors to the study of emotional stability, the role of emotional arousal in extreme conditions of activity is analyzed. Since emotional arousal is characterized by a state of activation of various functions of the body, an increase in mental readiness to unexpected different actions, it is a necessary condition for the use of personality resources for the successful performance of activities.

Polish psychologist J. Reikovsky, dwelling on emotional stability as a hypothetical feature of a person, speaks of two of its meanings:

1) a person is emotionally stable if his emotional arousal, despite strong stimuli, does not exceed the threshold value;

2) a person is emotionally stable, since despite strong emotional excitement, there are no violations in his behavior.

The main directions of research on emotional stability according to J. Reikovsky are:

1. "Physiological" direction, which requires the recognition that differences in stability are associated with differences in the nervous system as a whole or in one or another of its structures. A great contribution to the study of this problem was made by the concept of the type of the nervous system developed by Pavlov. The study of temperament based on this concept has greatly contributed to the understanding of the phenomenon of emotional stability. Emotional stability, apparently, largely depends on a property that was called "the reactivity of the individual", or in earlier works, the strength of the nervous system. Reactivity characterizes the body's ability to receive stimuli, namely the value of the sensitivity threshold and 
the threshold for working capacity. Other properties of temperament (mobility, poise) affect the emotional stability of the individual. It has been established that resistance to a certain kind of stress factors depends on the balance of nervous processes.

2. "Structural" direction, which assumes that the process of personality formation, which consists in the formation of more and more complex, differentiated and centralized regulatory structures, ultimately creates in the personality such subsystems, the specific features of which make a person more or less susceptible to the action of emotional stimuli; to study the emotional stability of a person, it is necessary to clarify the types and relationships of these subsystems, as well as their specific properties.

3. Search for a "special mechanism" of emotional stability. It is assumed that in humans, in addition to other regulatory mechanisms, there are also special "control mechanisms" that exercise something like supervision over the course of activity and support this activity, despite the influence of disturbing emotional factors.

4. Revealing the emotional characteristics of emotional stability. Each mental process (cognitive, emotional, volitional) is relatively independent of others and has specific characteristics. With regard to the emotional process, this means that neither volitional, nor cognitive processes, and even more so personality traits (orientation, temperament, character, abilities), despite the interconnections, are not necessarily included in its composition. The fourth approach is based on identifying the actual emotional characteristics of emotional stability [8].

M. Dyachenko and V. Ponomarenko distinguishes the following determinants of emotional stability:

1) emotional: emotional assessment of the situation, emotional anticipation of the course and result of the activity; the emotions and feelings experienced in this situation, the emotional experience of the individual (emotional attitudes, images, past experiences in this kind of situations);

2) nonemotional: the orientation of the personality, its needs, motives, volitional qualities, knowledge, skills, abilities, the type of the nervous system, etc. Emotional determinants affect emotional stability directly, others (non-emotional) - mainly refracted through them [7].

P. Zilberman, considering emotional stability as adaptation to an emotionally significant situation, identifies two of its stages:

1 ) the stage of emotional reactivity, which is characterized by vegetative shifts that occur in the body under the influence of emotiogenic impact;

2) the stage of emotional adaptation to the vegetative shifts that have arisen in the body, its meaning is to suppress the emerging vegetative shifts and self-regulation aimed at preserving purposeful behavior [1]
K. Platonov identifies the following types of emotional stability:

1) emotional-volitional stability - this is the degree of volitional possession of a person by his rather strong emotions;

2) emotional-motor stability is a personality trait, manifested in the degree of impairment of psychomotor activity under the influence of emotions;

3) emotional and sensory stability is a personality trait manifested in the degree of impairment of sensory actions [6].

Research by V. Ponomarenko show that emotional stability as a personality trait is a unity of components: motivational, emotional, volitional, intellectual.

Motivational component. The strength of motives largely determines emotional stability. One and the same person can find a different degree of it depending on what motives induce him to be active. Changing motivation can increase (or decrease) emotional stability. Motivation is determined by the worldview. Emotional stability depends on a person's attitude to the phenomena of reality, on his individual philosophy. The same phenomenon, depending on what place it occupies on the scale of a person's values, has a different effect on his mental state - the attitude towards him can be either indifferent or affective. Due to the different attitude of a person to the phenomena of reality, the psyche also plays the role of a selector of external influences - it selectively perceives some and ignores others. A person's attitude to reality is primarily determined by the content and magnitude of his needs, the strength of his desire for achievements, for self-improvement, the level of aspirations, the significance of those goals that he sets for himself, the role that he would like to play in society, based on an assessment of his capabilities, self-confidence.

Emotional component. Emotional experience of a person, accumulated in the process of overcoming the negative influences of extreme situations. As new emotions unfold on the basis of an already existing background state, interaction occurs between the states, resulting in mutual reinforcement or weakening. It depends on the sign of emotions (states of the same name are enhanced, and opposite ones are weakened), the prevailing emotional states in a person (what and how often he experiences emotions, what is their duration, depth and strength), how a person relates to his experiences.

Strong-willed component. It is expressed in the conscious self-regulation of actions, bringing them in line with the requirements of the situation. In addition to influencing external objects, human activity is directed to the organization of the activity itself. The essence of volitional behavior is the subordination of actions to leading motives, long-term plans, tasks arising from a reasonable assessment of the situation. Lack of will manifests itself in disorganization, 
which puts a person in conditions of constant lack of time, which causes chronic tension.

Intelligent component. This is an assessment and determination of the requirements of the situation, forecasting its possible change, making decisions about the methods of action. Emotional stability depends on the quality of mental activity, intelligence. The main purpose of thinking is to manage practical activities, obtain the information necessary for this, solve all kinds of life problems, develop an adequate attitude to emerging problems, find effective means and methods of activity, affect the mental state of a person and the degree of ability to predict the consequences of their actions [7].

Thus, the emotional stability of students, as a readiness for constructive solutions to emotive situations in professional activity, in our study is represented by the unity of four components. The motivational component of emotional stability is determined by a system of motives aimed at overcoming psychological barriers that arise in a stressful situation, which is expressed in the presence of motivation to achieve success and in the absence of motivation to avoid failures.

The volitional component of emotional stability is understood by us as internal or internal control of the individual over his behavior, the ability to take responsibility for his actions on himself. The emotional component of emotional stability is determined by the measure of the subject's sensitivity to critical situations of life, the level of his excitability, negative emotional experiences, situational and personal anxiety. Anxiety is a stable personality psychological feature caused by weakness of nervous processes, manifested in emotional discomfort, anticipation of trouble, impending danger and anxiety.

The cognitive component of emotional stability is characterized by the severity of intellectual emotions that determine the cognitive activity of an individual in self-organization and self-regulation of behavior. Cognitive activity is a person's inherent curiosity, a direct interest in the world around him, something that activates the cognitive activity of the subject.
Conclusions. The positive manifestation of the named components implements: the ability for full self-realization, personal growth with timely and adequate resolution of intrapersonal conflicts (value, motivational); the relative stability of the emotional tone and favorable mood, the ability for emotionalvolitional regulation, motivational tension adequate to the situation. At the same time, students develop the ability to withstand external influences, following their intentions and goals, improve themselves in the processes of mental self-government, self-regulation, and self-control.

Further prospects in this direction are to study the conditions of formation and development of stress and adaptive potential of emotional stability. We assume the presence of close correlations between the level of emotional stability and the effectiveness of overcoming emotional disruptions resilience in this case will indicate the severity of stress and adaptive capabilities of the individual.

\section{REFERENCES}

1. Вилюнас В. Основные проблемы психологической теории эмоций. Психология эмоций / под ред. В. Вилюнаса, Ю. Гиппенрейтер. Москва : МГУ, 1984. C. 3-29.

2. Зильберман П. Эмоциональная устойчивость и стресс. Психический стресс в спорте : материалы Всесоюзного симпозиума. Пермь, 1973. С. 13-15.

3. Ковалев А. Психическое развитие ребенка и жизненная среда. Вопросы психологии. 1993. № 1. С. 13-23.

4. Левин К. Динамическая психология: избранные труды / общ. ред. Д. Леонтьева, Е. Патяевой. Москва : Смысл, 2001. 572 с.

5. Ожегов С. Словарь русского языка : около 60000 слов и фрразеологических оборотов / под общ. ред. Л. Скворцова. 25-е изд., испр. и доп. Москва : Оникс, 2007. 973 с

6. Платонов К. Структура и развитие личности. Москва : Наука, 1986. 378 с.

7. Пономаренко В. Профрессия - психолог труда. Москва : Институт психологии РАН, 2007. 400 с.

8. Рейковский Я. Экспериментальная психология эмоций. Москва : Прогресс, 1979. 391 с. 